удК 336.71

\title{
ОПОДАТКУВАННЯ БАНКІВСЬКОї ДІЯЛЬНОСТІ В УКРАЇНІ ТА ОСНОВНІ НАПРЯМИ ЙОГО ВДОСКОНАЛЕННЯ
}

\section{TAXATION OF BANKING ACTIVITY IN UKRAINE AND MAIN DIRECTIONS OF ITS IMPROVEMENT}

\author{
Шевченко Любов Ярославівна \\ кандидат економічних наук, доцент, \\ Донецький національний університет економіки і торгівлі \\ імені Михайла Туган-Барановського \\ ORCID: https://orcid.org/0000-0003-2188-1735 \\ Куліш Анастасія Валеріївна \\ здобувач вищої освіти, \\ Донецький національний університет економіки і торгівлі \\ імені Михайла Туган-Барановського \\ ORCID: https://orcid.org/0000-0001-5332-0604 \\ Shevchenko Lyubov, Kulish Anastasiia \\ Donetsk National University of Economics and Trade \\ named after Mykhailo Tugan-Baranovskyi
}

\begin{abstract}
Стаття присвячена актуальним питанням оподаткування банківської діяльності в Україні. Розглянуто роль банківських установ у податковій системі, запропоновано можливі напрямки удосконалення, визначено комплекс основних операцій банківської діяльності. Банківські установи відіграють важливу роль в економіці кожної країни, їх діяльність має свої специфічні особливості та ризики. Оскільки банки є суб'єктами господарювання, метою їх діяльності в умовах ринкового середовища є отримання максимального прибутку. Через це механізм оподаткування банківських установ має певні особливості незважаючи на те, що зараз їх податкове регулювання відбувається відповідно до вимог законодавства. Нестабільне економічне середовище лише посилює значення системи оподаткування банківських установ, тому що воно має комплексний та взаємопов'язаний характер.
\end{abstract}

Ключові слова: банківські установи, облік, оподаткування, податки, банківська діяльність.

Статья посвящена актуальным вопросам налогообложения банковской деятельности в Украине. Рассмотрена роль банковских учреждений в налоговой системе, предложены возможные направления совершенствования, определен комплекс основных операций банковской деятельности. Банковские учреждения играют важную роль в экономике каждой страны, их деятельность имеет свои специсические особенности и риски. Поскольку банки являются субъектами хозяйствования, целью их деятельности в условиях рыночной среды является получение максимальной прибыли. Поэтому механизм налогообложения банковских учреждений имеет определенные особенности несмотря на то, что сейчас их налоговое регулирование осуществляется в соответствии с требованиями законодательства. Нестабильная экономическая среда только усиливает значение системы налогообложения банковских учреждений, так как оно имеет комплексный и взаимосвязанный характер.

Ключевые слова: банковские учреждения, учет, налогообложение, налоги, банковская деятельность.

The article is devoted to topical issues of banking taxation in Ukraine. The role of banking institutions in the tax system is considered, possible directions of improvement are offered, the complex of the basic operations of banking activity is defined. Banking institutions play an important role in the economy of each country, their activities have their own specific features and risks. Because banks are businesses, the goal of their operations in a market environment is to maximize profits. Due to this, the mechanism of taxation of banking institutions has certain features, despite the fact that now their tax regulation is in accordance with the requirements of the law. An unstable economic environment only reinforces the importance of the banking system's taxation system because it is complex and interconnected. The value of taxes and features of the taxation system of banks is due to the functions of taxes, the 
main of which are two - fiscal and regulatory. In terms of influencing the activities of banks, the regulatory function of taxes is of paramount importance, because it is through it that the state balances its interests with the interests of taxpayers. As a direct factor, the taxation system of banks affects the following indicators of their activities - the cost of products and services, costs and financial results, which affect the liquidity of the bank and the amount of own funds, because taxes, like any costs, reduce profits, and hence the capital of the bank. Banks are intermediaries in the transfer of taxes and fees of legal entities and individuals to the budget, they perform the functions of tax agents withhold and transfer to the budget income tax, tax on the purchase of cash foreign currency and other taxes, fees and charges. Taxes, regardless of the source of their payment, are expenses for the bank. At the same time, the price of a banking product is formed from costs and profits. Hence, reducing the tax burden should help achieve the following goals: increase the attractiveness of banking products; reduction of production costs of the bank's clients and increase of their business activity, as well as receipts of tax payments to the budget; reduction of bank rates and tariffs for services; stimulating the development of competition in banking.

Keywords: banking institutions, accounting, taxation, taxes, banking activity.

Постановка проблеми. Система оподаткування банківських установ не має попиту у вивченні серед науковців, тому що досвід країн, котрі переходять до ринкової економіки та існуюча практика податкового регулювання не дають змоги зробити висновки на базі емпіричних даних. Також, податкове регулювання банківських установ та відносини банків 3 податковою системою мають покращуватися. Адже неякісно складена та не удосконалена нормативно-законодавча база приводить до ухилення від сплати податків. Саме це не дає можливості розвитку банківських установ та негативно впливає на розвиток економіки України.

Аналіз останніх досліджень і публікацій. Особливості оподаткування банківської діяльності вивчали як закордоні, так і вітчизняні вчені. Вагомий внесок у розгляд цього питання внесли такі науковці - К. Проскура, А. Гальчинський, К. Молодико, В. Валюка, І. Бобкова та інші. Ці вчені приділили багато уваги даному питанню.

Виділення невирішених раніше частин загальної проблеми. Незважаючи на попит у вивченні цього питання серед науковців, досі залишились не досліджені елементи особливостей оподаткування банківських установ, котрі потребують детального вивчення. Податкове регулювання банківських установ потребує вдосконалення.

Формулювання цілей статті (постановка завдання). Головною метою написання цієї статті $€$ дослідження оподаткування банківської діяльності в Україні. Основне завдання полягає у визначенні нових напрямків вдосконалення системи оподаткування банківських установ.

Виклад основного матеріалу дослідження. Банківська система займає важливе місце у здійсненні економічної політики країни, оскільки виступає сполучною ланкою в еконо- міці. Саме через це більш детальне вивчення питання оподаткування банківських установ та їх прибутку, визначення особливостей податкового регулювання банківських установ стає актуальним та необхідним. Оскільки з часом деякі аспекти цього питання застаріли та потребують перегляду й вдосконалення деяких нормативно-законодавчих елементів. Необхідно пам'ятати що ці питання потрібно вивчати не лише з боку забезпечення стабільності та стійкості роботи банківських установ, а також з боку впливу банків на економічний розвиток країни.

Сучасний стан розвитку банківської системи знаходиться у кризовому становищі та потребує вдосконалення й розробки нових підходів управління банківськими установами, створення та успішної реалізації стратегії банківської діяльності.

Розвиток банківського сектору має важливе значення, оскільки саме банківські установи забезпечують сталу роботу різних підприємств, організацій та людей у взаємодії між собою. Через загострення світових криз, розвиток потреб людства, тенденцію до соціалізації економіки, з'являється потреба у реформуванні податкового регулювання банківських установ. Впровадженню нових дієвих податкових стимулів заважає безліч існуючих фракторів, через це потрібно детально вивчити законодавчу базу банківського сектору та визначити шляхи покращення оподаткування фрінансових результатів банківських установ.

Банківські установи у податковій системі мають подвійну роль. Банки виступають суб'єктами податкових відносин, тобто постають платниками податків, котрі відносяться до бюджетів різних рівнів. Від них залежить своєчасне здійснення переказів від платників податків до державної казни, її повнота обсягів. Також, банківські установи 
здійснюють валютний та податковий контроль, котрий відбувається завдяки надання інфрормації про відкриття рахунків клієнтами, їх фрінансові операції, своєчасне здійснення переказів податків. Банківські установи постають головними серед інвесторів діючого сектору економіки, саме цим вони збільшують кількість платників податків, створюють додаткові матеріальні блага та підвищують дохідність бюджетної системи [1].

Недосконала нормативно-законодавча база призводить до надмірного оподаткування одних банківських операцій й недостатнього оподаткування інших. Саме через це банківські установи та діючий сектор економіки не можуть стабільно розвиватись.

Банківські установи у своїй діяльності постійно ризикують, оскільки їх операції оподатковуються і відносяться до операцій особливого виду. Банківська діяльність складається з комплексу основних операцій:

- здійснення розрахунків між клієнтами;

- прийняття грошових вкладів від клієнтів;

- надання клієнтам кредитів.

Вітчизняні науковці виділяють два підходи оподаткування банківських установ. Відповідно до першого, банки мають оподатковуватися за вищою ставкою, ніж інші суб'єкти господарювання. Оскільки, банківські установи постають фрінансовими посередниками, котрі не створюють видимих матеріальних благ, тобто вони мають надприбуток. Другий підхід представляє банки генератором фрінансової активності та створює баланс орінансових потоків країни. Перешкоджаючи цій діяльності, господарська діяльність матиме занепад [2].

Незалежно від джерела сплати, витратами для банківських установ $є$ податки. Але незважаючи на це, ціна банківського продукту залежить від прибутку та витрат. Якщо податки зменшуються, то це має призвести до більшого попиту на банківські послуги, зменшення тарифрів банківських установ на свої послуги, зменшення витрат клієнтів банку та підвищення рівня їх активності [3].

Головними проблемами, котрі заважають розвиватися банківській системі України на даному етапі є спад в економіці, девальвація гривні, військові дії на сході країни й анексія AP Криму. Саме це призвело до низького рівня управління та погіршення якості кредитного порторелю державних банківських установ. Через підвищення рівня заборгованостей банківські установи створюють резерви за активними операціями. Ці дії негативно впливають на рівень капіталізації банків. Незважаючи на податкові реформи, які мають позитивний вплив на розвиток банківської діяльності, все одно у банківських установ залишається можливість уникати сплати податків й інших обов'язкових платежів.

Для покращення системи оподаткування банківських установ потрібно активізувати стимулюючу фрункцію податкового регулювання. Саме завдяки їй створяться необхідні макроекономічні умови, котрі сприятимуть фрормуванню стабільності банківської системи, з часом вона стане дієвим інструментом інвестиційного процесу та рівень економіки країни почне зростати. Податкове регулювання банківських установ не повинно впливати на рівень фрінансової стійкості.

Також для удосконалення оподаткування банківських установ необхідно визначити оптимальний рівень їх податкового навантаження. Наприклад, податкове навантаження з податку на прибуток у фрінансовому результаті банківської установи визначається відношенням розміру сплаченого податку на прибуток до різниці між доходами і витратами. 3 ініціативи держави має бути створена модель завдяки якій банки зможуть оцінити ефективність дій податкового менеджменту, а держава буде бачити та відслідковувати, котрим банківським установам потрібний вищий рівень податкового регулювання та контролю. Ця модель дасть змогу знайти баланс між потребами держави та банківськими установами, як платниками податків [4].

Висновки. Отже, підсумовуючи вищевикладене та проаналізувавши систему оподаткування банківських установ, можна зробити висновок, що в системі оподаткування банківської діяльності існують проблеми, котрі заважають їй розвиватися та удосконалюватися. Саме за допомогою податків можна впливати на діяльність банків. Головним завданням такого впливу постає зміна вкладень банків у діючий сектор економіки, а не в спекулятивні інструменти банківських установ.

Для вдосконалення системи оподаткування банківських установ, необхідно створити таку систему оподаткування банків, котра буде стимулювати банківські установи збільшувати вкладення капіталу в діючий сектор економіки, збільшуючи рівень доходів, а це означає, що буде збільшуватися оподатковуваний прибуток. 


\section{СПИСОК ВИКОРИСТАНИХ ДЖЕРЕЛ:}

1. Клюско Л.А., Підсонна А.Г. Оподаткування банківської діяльності в Україні та основні напрямки його вдосконалення. 2012. URL: http://fkd.org.ua/article\%20/viewFile/28913/25917

2. Кміть В.М., Савоцька М.Я. Напрями вдосконалення системи оподаткування діяльності банківських установ. Науковий вісник Міжнародного гуманітарного університеmу. 2018. URL: http://vestnik-econom.mgu.od.ua/ journal/2018/33-2018/16.pdf

3. Здобувач О.Г. Вплив оподаткування на доходність і напрями розвитку банківської діяльності. Науковий вісник НЛтУ України. 2010. URL: https://nv.nltu.edu.ua/Archive/2010/20_4/262_Serbyna_20_4.pdf

4. Пашкурова Н.П. Оподаткування прибутку комерційних банків: тенденції та проблемні аспекти. Міжнародна науково-практична інтернет-конференція «Соціум. Наука. Культура». URL: http://intkonf.org/ pashkurova-np-opodatkuvannya-pributku-komertsiynih-bankiv-tendentsiyi-ta-problemni-aspekti/

\section{REFERENCES:}

1. Kliusko L.A., Pidsonna A.H. (2012) Opodatkuvannia bankivskoi diialnosti v Ukraini ta osnovni napriamky yoho vdoskonalennia [Taxation of banking activity in Ukraine and the main directions of its improvement]. URL: http://fkd.org.ua/article\%20/viewFile/28913/25917

2. Kmit V.M., Savotska M.Ya. (2018) Napriamy vdoskonalennia systemy opodatkuvannia diialnosti bankivskykh ustanov. [Directions for improving the system of taxation of banking institutions]. Naukovyi visnyk Mizhnarodnoho humanitarnoho universytetu. URL: http://vestnik-econom.mgu.od.ua/journal/2018/33-2018/16.pdf

3. Zdobuvach O.H. (2010) Vplyv opodatkuvannia na dokhodnist i napriamy rozvytku bankivskoi diialnosti [The impact of taxation on profitability and development of banking]. Naukovyi visnyk NLTU Ukrainy. URL: https://nv.nltu.edu.ua/Archive/2010/20_4/262_Serbyna_20_4.pdf

4. Pashkurova N.P. Opodatkuvannia prybutku komertsiinykh bankiv:tendentsii ta problemni aspekty. [Income taxation of commercial banks: trends and problematic aspects]. Mizhnarodna naukovo-praktychna internet-konferentsiia «Sotsium. Nauka. Kultura». URL: http://intkonf.org/pashkurova-np-opodatkuvannya-pributku-komertsiynih-bankiv-tendentsiyi-ta-problemni-aspekti/ 